\title{
Uppermost Lower Aptian transgressive records in Mexico and Spain: chronostratigraphic implications for the Tethyan sequences
}

\author{
Josep A. Moreno-Bedmar, ${ }^{1}$ Telm Bover-Arnal, ${ }^{2}$ Ricardo Barragán ${ }^{1}$ and Ramon Salas ${ }^{3}$ \\ ${ }^{1}$ Instituto de Geología, Universidad Nacional Autónoma de México, Ciudad Universitaria, Coyoacán, 04510, México, D.F., Mexico; \\ ${ }^{2}$ Département de Géosciences, Université de Fribourg, Chemin du Musée 6, 1700, Fribourg, Switzerland; ${ }^{3}$ Departament de Geoquímica, \\ Petrologia i Prospecció Geològica, Facultat de Geologia, Universitat de Barcelona. Martí i Franqués s/n, 08028, Barcelona, Spain
}

\begin{abstract}
A widespread marine transgression, which began at the very end of the Early Aptian, is well recorded in Mexico and Spain. In Mexico, this transgression was the most important Aptian transgressive event and its record begins in the Dufrenoyia justinae Zone, whereas in Spain the corresponding transgression is registered in the uppermost part of the Dufrenoyia furcata Zone. The basal age of this Tethyan transgression does not correspond exactly to any of the Lower Aptian third-order sequences as reported in the literature. In Spain, the most important Aptian transgressive event was earlier, correspond-
\end{abstract}

ing to the Tethyan sequence Ap3, which is well-defined below this transgression reported herein. Consequently, it is possible to correlate this later transgressive event with the third-order Ap4 sequence, which has commonly been attributed to the Upper Aptian. The available ammonoid data allow us to correct the basal age of the transgression, and to correlate the start of the ammonite record in Mexico with the Tethyan sequence Ap4.

\section{Introduction}

Mesozoic third-order sequences reflecting changes of relative sea-level have been recognized in basins of the western Tethys in Europe (Hardenbol et al., 1998). The calibration by means of biostratigraphic data of these thirdorder sequences makes it possible to establish correlations between different basins of Tethys (e.g., Pasquier and Strasser, 1997; Röhl and Ogg, 1998; Hillgärtner et al., 2003; Colombié and Strasser, 2005; Yose et al., 2006; Bover-Arnal et al., 2009, 2010a). For the Mesozoic Era, the age calibration of these sequences is essentially based on ammonite biostratigraphy, as this typically provides the highest biostratigraphic resolution. At the same time, this work is framed in a transgressive context in which the ammonoid provincialism diminishes or disappears (e.g., Kennedy and Cobban, 1976; Cecca et al., 2005; Latil, 2011).

At the start of modern sequence stratigraphy, Vail et al. (1977) proposed that the seismic-scale sequences that they recognized in seismic profiles

Correspondence: Josep Anton MorenoBedmar, Instituto de Geología, Universidad Nacional Autónoma de México, Ciudad Universitaria, Coyoacán, 04510, México, D.F., Mexico. Tel.: +52 5556224280 ext. 233; fax: + 5255 55506644; e-mail: josep amb@geologia.unam.mx. were generated by worldwide changes in sea level. Thus, eustasy would have been an important factor in controlling accommodation on a long-term scale throughout geologic time. This imputes a global and synchronous character to the sequences. In effect, the sequences of Hardenbol et al. (1998) are thought to have been controlled in great part by eustasy, although at a local to regional scale tectonics would have also exerted control on the available depositional space. Major phases of tectonic control affect the volume of ocean basins, and can produce synchronous and global sequences similar to eustasy (e.g., Cloetingh, 1986, 1991). In addition, some studies have pointed out that these third-order sea-level events identifiable throughout Tethys were not always synchronous (e.g., Immenhauser and Scott, 1999). However, it is widely assumed that most of the Hardenbol's Mesozoic sequences had a Tethyan significance and can thus be recognized in different basins of Tethys (e.g., Röhl and Ogg, 1998; Gradstein et al., 2004). Therefore, when establishing trans-Tethyan correlations with

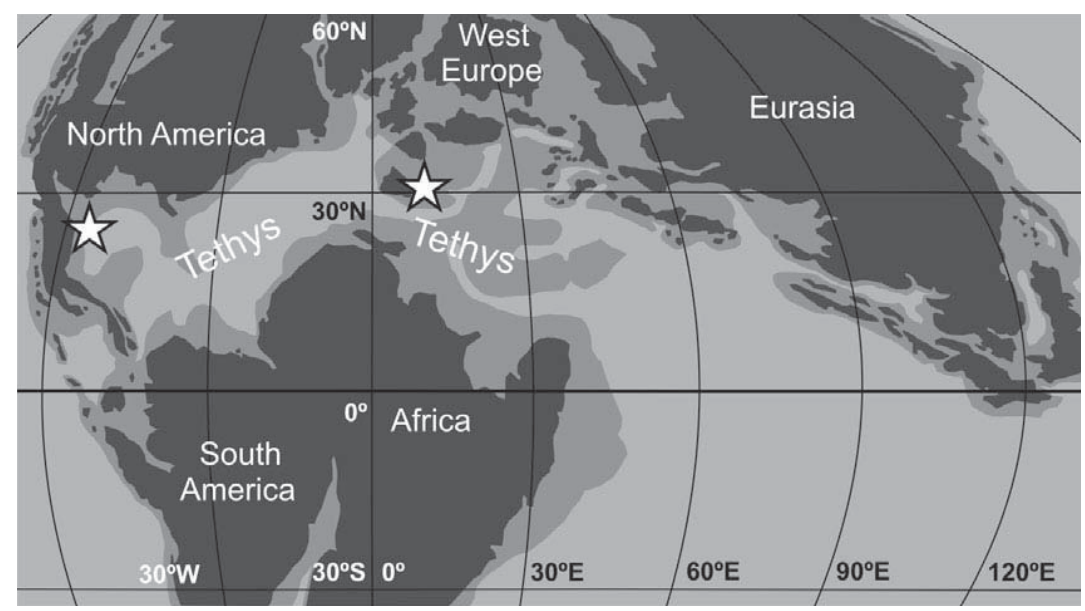

Fig. 1 Palaeogeographical reconstruction of the Tethyan realm during the late Early Cretaceous (120 Ma) (modified from http://www2.nau.edu/rcb7/mollglobe.html). The left star shows the location of the Durango area of north-east Mexico and the right star shows the Maestrat Basin of eastern Spain. 
these sequences a precise biostratigraphic control is needed.

In this paper we study the Aptian (Early Cretaceous) transgressive event corresponding to the Tethyan sequence Ap4 of Hardenbol et al. (1998), in Mexico and Spain (Fig. 1). These transgressive deposits contain an excellent ammonoid record characterized by the presence of the youngest species of the genus Dufrenoyia. This biostratigraphic control allows us to make a trans-Tethyan correlation. The comparison between the Mexican and Spanish transgressions permits the recognition of similarities and differences between both sedimentary records, as well as constraining the age of the boundary between the Aptian Tethyan sequences Ap3 and Ap4. In addition, we can contrast the correlation of the standard ammonite Mediterranean zonation of Reboulet et al. (2011), which was essentially established in western Tethys, with the Mexican Lower Aptian zonation, Atlantic extension of the Tethys.

\section{The Mexican transgression}

Several authors have documented the beginning of the ammonoid record in the lower part of the transgressive deposits, which are known as the La Peña or Otates formations. These transgressive strata usually overlie the platform carbonates of the Cupido Formation (Burckhardt, 1925; Humphrey, 1949; Cantu Chapa, 1963; Cantú Chapa, 1976; Barragan, 2001; Barragán and Maurrasse, 2008). In Mexico, the dominant taxon of these transgressive deposits is $D u f$ renoyia justinae (Hill, 1893) (Fig. 2). This ammonoid is recognized in several localities and sections, such as FZD: Francisco Zarco Dam Section (Fig. 3) in the state of Durango in north-east Mexico (Barragan, 2001 for location).

The same transgression is also well known in other parts of the Atlantic extension of Tethys, including the United States (e.g., Hill, 1893; Stoyanow, 1949), Colombia (e.g., Riedel, 1938; Etayo-Serna, 1979) and Venezuela (e.g., Renz, 1982; Arnaud et al., 2000). In most of these countries, the Aptian ammonoid record seems to begin with Dufrenoyia beds. Accordingly, the magnitude of the transgression related to the Dufrenoyia beds is
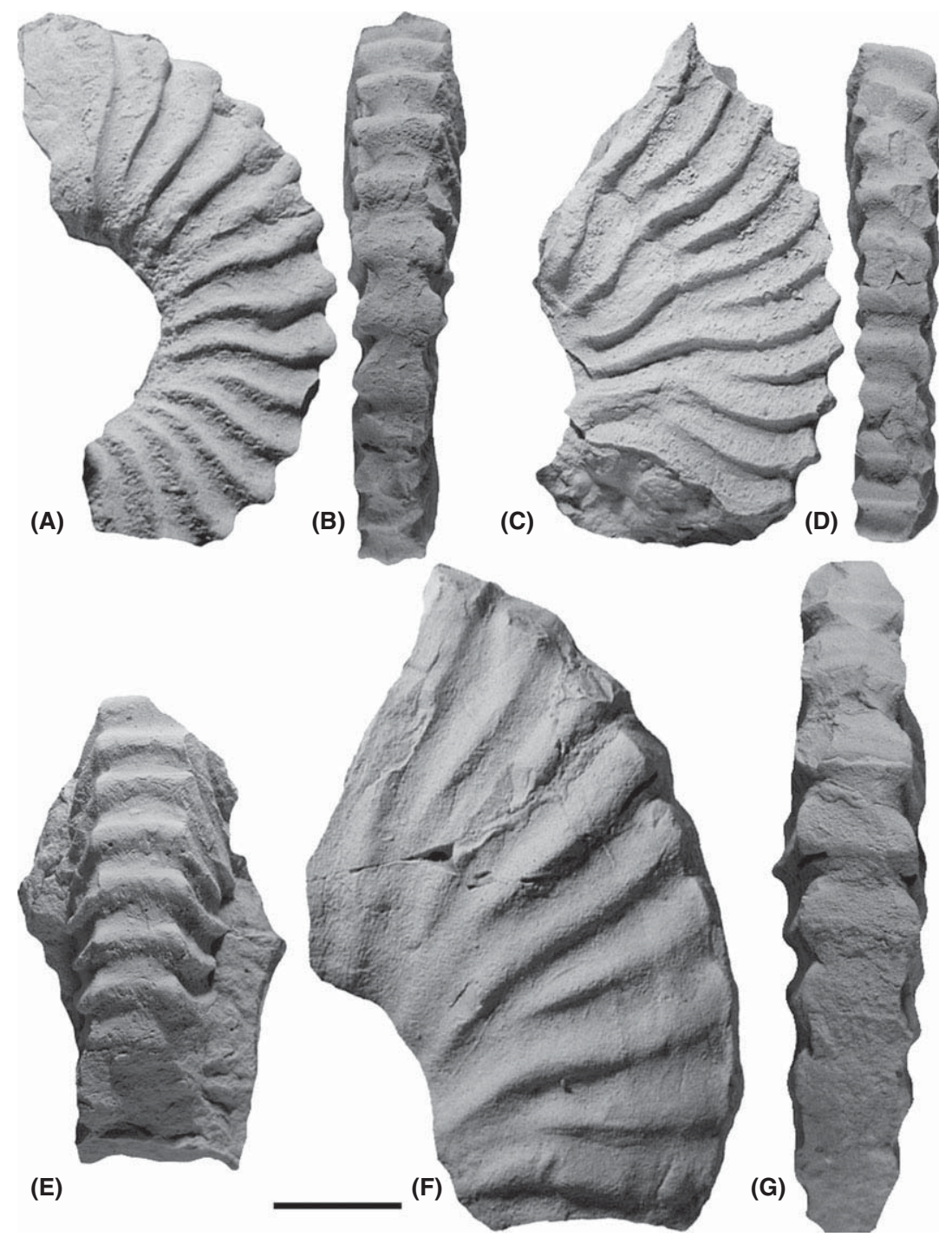

Fig. 2 Dufrenoyia justinae specimens collected in the Francisco Zarco Dam section (State of Durango; NE Mexico). A-B: Dufrenoyia justinae lateral and ventral views of the specimen IGM 6131 (Museo María del Carmen Perrilliat M., Colección Nacional de Paleontología, Instituto de Geología, Universidad Nacional Autónoma de México, México D.F., Mexico), bed 81. C-D: Dufrenoyia justinae lateral and ventral views of the specimen IGM 6132, bed 68. E: Dufrenoyia justinae ventral view of the specimen IGM 6133, bed 67. F-G: Dufrenoyia justinae lateral and ventral views of the specimen IGM 6134, bed 85 . Scale bar $=1 \mathrm{~cm}$.

of widespread significance in the Atlantic extension of Tethys.

\section{The Spanish transgression}

In the Maestrat Basin (eastern Spain), Salas (1987) identified the presence of a marine transgression at the base of the Benassal Formation. The base of this formation has been recently correlated in the western part of the basin with the upper part of the Dufrenoyia dufrenoyi Subzone (uppermost part of the Dufrenoyia furcata Zone; uppermost Lower Aptian) by Moreno-Bedmar (2010) (Fig. 3). The same transgressive event is being studied in the northern sector of the Maestrat Basin (Bover-Arnal et al., 2010b), where several specimens of the index species Dufrenoyia dufrenoyi (d'Orbigny, 1841) have been collected (Figs 3 and 4). Therefore, the Dufrenoyia dufrenoyi Subzone is also recorded in this northern part of the basin. Presently, this age assignment is recognized 


\section{Mexico}

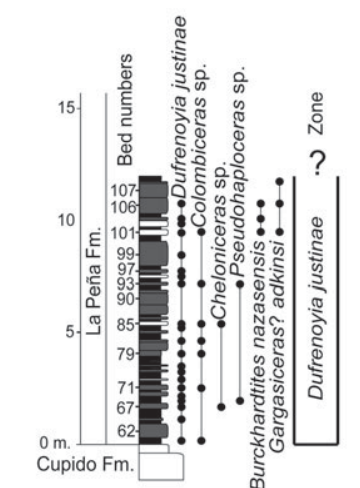

Francisco Zarco Dam section
Spain

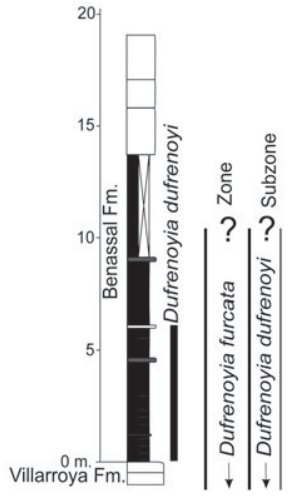

Mola de la Vila section

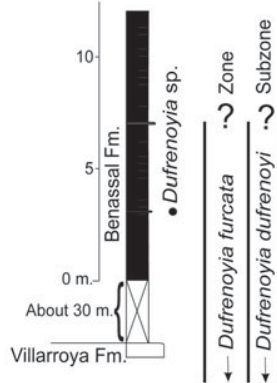

Villarroya de los Pinares section

Ex situ ammonoids
Shaly limestone

Limestone
Marls

Nodular marly limestone Limestone
- In situ ammonoids

Fig. 3 Francisco Zarco Dam section, north-east Mexico (Barragan, 2001 for situation) and Mola de la Vila and Villarroya de los Pinares sections, eastern Spain (see Bover-Arnal et al., 2010a, b).
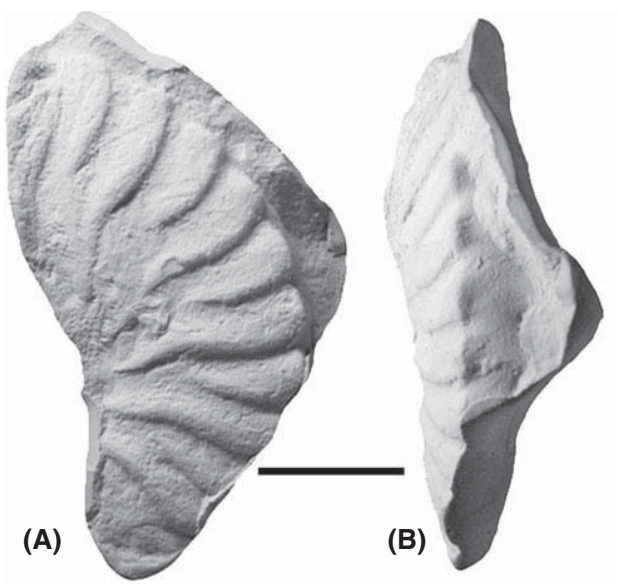

(C)

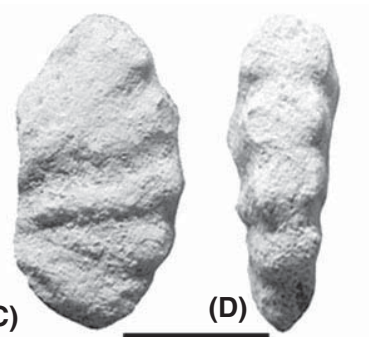

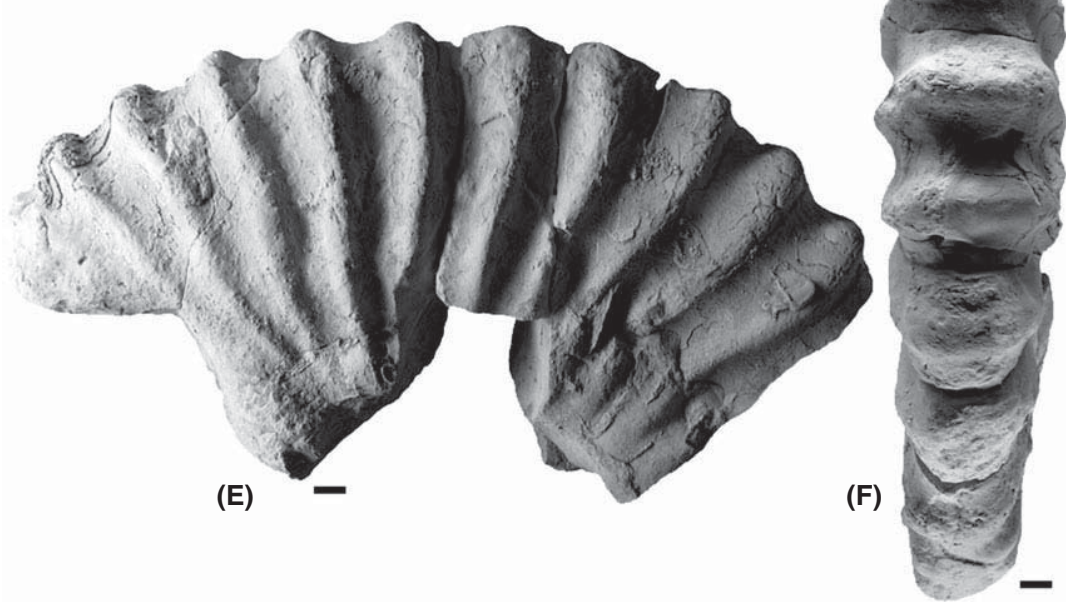

in three sections of these two sectors of the Maestrat Basin: Villarroya de los Pinares (W Maestrat Basin), Mola de la Vila and Mola de la Garumba (N Maestrat Basin) (see Bover-Arnal et al., 2010a,b for situation). The Villarroya de los Pinares and Mola de la Vila sections are shown in Fig. 3. The Tethyan sequence Ap3 is well recorded beneath this transgression in the Forcall and Villarroya de los Pinares formations (Bover-Arnal et al., 2010a), and calibrated by means of ammonoids (Moreno-Bedmar et al., 2010). Consequently, the later transgressive event can be assigned to the third-order sequence Ap4.

In the Basque-Cantabrian Basin ( $\mathrm{N}$ Spain), the presence of transgressive strata containing Dufrenoyia specimens has recently been recognized in the lowermost part of Lareo Formation (Millán et al., 2007; GarcíaMondéjar et al., 2009). According to the ammonoid biostratigraphic analysis carried out by these authors, the Errenaga and Sarastarri formations, which are stratigraphically below the Lareo Formation, are coeval with the Tethyan Sequence Ap3 of Hardenbol et al. (1998). Thus, these transgressive deposits can be assigned to the Tethyan Sequence Ap4.

\section{The succession of Dufrenoyia species in Spain}

A clear succession of two species of Dufrenoyia is recorded in Spain. The first one is Dufrenoyia furcata (Sowerby, 1836) and the second one is Dufrenoyia dufrenoyi (d'Orbigny, 1841). This succession has been also recognized in the Vocontian Basin (France) by Dutour (2005). These two species give name to two subzones of the Dufrenoyia furcata Zone, which

Fig. 4 Dufrenoyia specimens collected in the Maestrat Basin (E Spain). A-B: Dufrenoyia dufrenoyi lateral and ventral views of the specimen PUAB 88390 (Collections of Paleontology of the Universitat Autònoma de Barcelona, Barcelona, Spain), Mola de la Vila section. C-D: Dufrenoyia dufrenoyi lateral and ventral views of the specimen PUAB 88391, Mola de la Garumba section. E-F: Dufrenoyia sp. lateral and ventral views of the specimen VP-A6, Villarroya de los Pinares section. Scale bar $=1 \mathrm{~cm}$. 
were recently proposed, accepted and published in Reboulet et al. (2011).

However, in the western margin of the Maestrat Basin (E Spain), a third species was recognized in the upper part of the Dufrenoyia dufrenoyi Subzone in the Barranco de las Calzadas section (see Bover-Arnal et al., 2010a, 2011 for details). This third taxon, identified as Dufrenoyia sp. in MorenoBedmar et al. (2010), shows great similarities to the New World species Dufrenoyia justinae. Accordingly, it should be referred as Dufrenoyia cf. justinae (see Fig. 5). These independent data support the correlation of the uppermost Lower Aptian transgressive records identified in Mexico and Spain.

\section{Age constraints of the limit between the Tethyan sequences Ap3 and Ap4}

Neither the Mexican nor the Spanish transgressions reported can be correlated with any of the Lower Aptian Tethyan Sequences (Ap1-Ap3) of Hardenbol et al. (1998). In Spain, the most important Aptian transgression corresponds to the transgressive part of the Sequence Ap3. This transgression has been studied thoroughly, in particular its maximum flooding zone, which is coeval with the Oceanic Anoxic Event 1a (García-Mondéjar

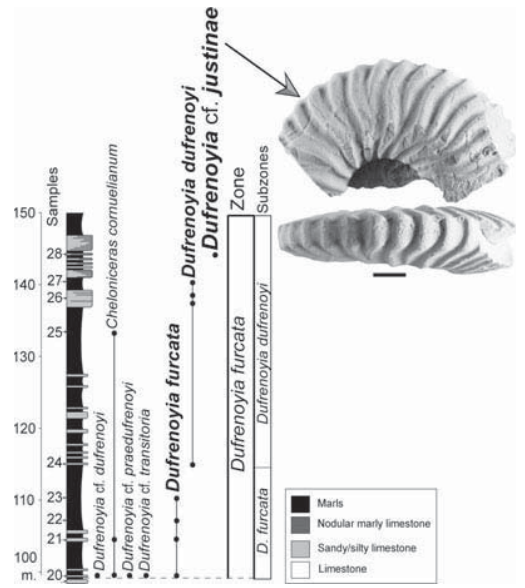

Fig. 5 Barranco de las Calzadas section, eastern Spain (modified of Moreno-Bedmar et al., 2010). In the upper right of the figure Dufrenoyia cf. justinae lateral and ventral views of the specimen CPT3728 (Collections of Conjunto Paleontológico de Teruel, Teruel, Spain). Scale bar $=1 \mathrm{~cm}$.

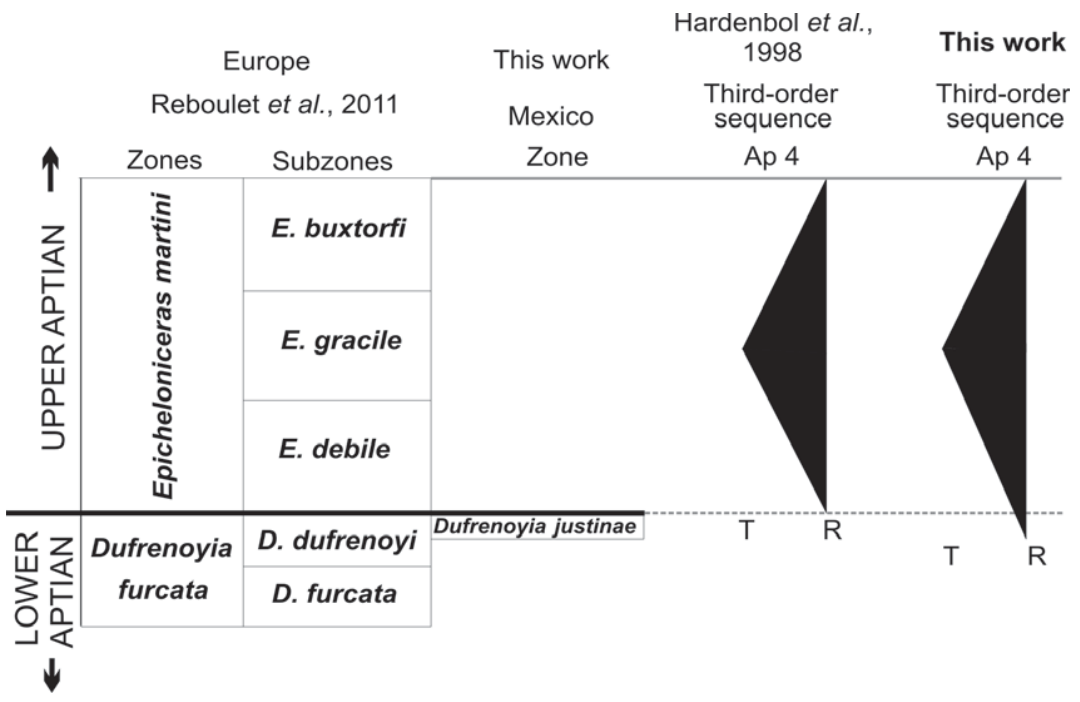

Fig. 6 The third-order sequence Ap4 with respect to the standard ammonite Mediterranean zonation of the uppermost Lower Aptian/lowermost Upper Aptian and the uppermost Lower Aptian ammonite Mexican zonation.

et al., 2009; Moreno-Bedmar et al., 2009, 2010, 2012; Bover-Arnal et al., 2010a, 2011; Najarro et al., 2011). The transgressive deposits above the Tethyan Sequence Ap3 contain the youngest Dufrenoyia species. Therefore, this latter transgression must be assigned to the sequence Ap4. According to Hardenbol et al. (1998), the Tethyan Sequence Ap4 commences with the Upper Aptian. However, our data in Spain show that this age must be corrected, if not globally, at least for the Cretaceous Iberian basins. In Iberia (Iberian plate), the start of the Ap4 should be placed in the uppermost part of the Dufrenoyia furcata Zone, more precisely in the upper part of the Dufrenoyia dufrenoyi Subzone (uppermost Lower Aptian) (Fig. 6).

In Mexico, the United States, Colombia and Venezuela, the strongest Aptian transgression recorded must be also assigned to the Ap4 sequence. This transgression consistently started with Dufrenoyia beds. Bralower et al. (1999) suggest that this transgression in Mexico was linked to the Oceanic Anoxic Event 1a (OAE 1a) that is related to the maximum flooding zone of the Ap3 sequence that occurred in the Deshayesites forbesi Zone, Roloboceras hambrovi Subzone (e.g. Moreno-Bedmar et al., 2009, 2010, 2012; Bover-Arnal et al., 2010a,b; Najarro et al., 2011; Reboulet et al.,
2011). Our data show that the Mexican transgression is not associated with the OAE 1a because it clearly occurs later in the Dufrenoyia justinae Zone in agreement with Millán et al. (2009) and Skelton and Gili (2012).

The Mexican zone Dufrenoyia justinae was correlated with the entire Dufrenoyia furcata Zone of the Tethyan realm (Barragán-Manzo and Méndez-Franco, 2005). According to the new data concerning the age of the boundary between the Ap3 and Ap4 sequences, the Dufrenoyia justinae Zone would only be an equivalent to the upper part of Dufrenoyia furcata Zone (Fig. 5). This interpretation is consistent with the first appearance of Dufrenoyia cf. justinae in an equivalent stratigraphic position in Spain. Unfortunately, our data are restricted to Mexico and Spain. Nevertheless, this basal age of the Tethyan Sequence Ap4 can probably be expanded into several other basins of the Old and New worlds.

\section{Conclusions}

The widespread transgressive event that occurred in Mexico and in the New World (Atlantic extension of Tethys) during the latest-Early Aptian has also been identified in Spain (western Tethys), and are both correlatable with the transgressive part of the Tethyan sequence Ap4 of Hardenbol et al. 
(1998). The ammonoid data permit us to calibrate the basal age of the Tethyan sequence Ap4 as follows: Dufrenoyia justinae Zone in Mexico and upper part of the Dufrenoyia dufrenoyi Subzone (uppermost part of the Dufrenoyia furcata Zone) in Spain. Accordingly, the boundary between the Tethyan sequences Ap3 and Ap4 is latest-Early Aptian in age, at least in the basins of these two countries. The transgressive event of the Tethyan sequence Ap4 is the most important Aptian transgression of the Atlantic extension of Tethys (New World), whereas in the western Tethys (Old World), the most important one is recorded in the Tethyan sequence Ap3. The correlation of the Tethyan sequence Ap4 between Mexico and Spain, and the succession of species of Dufrenoyia recognized in Spain, allow us to note that the Mexican ammonoid Zone Dufrenoyia justinae corresponds to the uppermost part of the Dufrenoyia furcata Zone of the western Tethys. Although differences exist in the sedimentary expression of the transgressions of sequences Ap3 and Ap4 in Mexico and Spain, the findings also highlight the Tethyan significance of these third-order sequences.

\section{Acknowledgements}

This study was supported by the grant PAPIIT IN108709 by DGAPA, UNAM the grants of the Swiss National Science Foundation (no. 20-121545.08), the Spanish Ministerio de Ciencia e Innovación (I $+\mathrm{D}+\mathrm{i}$ research project CGL2008-04916), the Consolider-Ingenio 2010 programme, under CSD 2006-0004 "Topo-Iberia" and the Grup Consolidat de Recerca "Geologia Sedimentària" (2009SGR-1451). We appreciate the help of Dra. Perrilliat and Violeta Romero Mayén in the study of the Mexican ammonoids that are housed in Museo María del Carmen Perrilliat M., Colección Nacional de Paleontología, Instituto de Geología, UNAM, México D.F. We are very grateful for the helpful corrections and suggestions made by Peter W. Skelton, an Associate Editor, and two anonymous reviewers.

\section{References}

Arnaud, H., Arnaud-Vanneau, A., Bulot, L.G., Beck, C., Macsotay, O., Stephan, J.-F. and Vivas, V., 2000. Le Crétacé inférieur du Venezuela oriental: stratigraphie séquentielle des carbonates sur la transversale Casanay-Maturin (États de
Anzoátegui, Monagas et Sucre). Géol. Alpine, 76, 3-81.

Barragan, R., 2001. Sedimentological and paleocological aspects of the Aptian transgressive event of Sierra del Rosario, Durango, northeast Mexico. J. S. Am. Earth Sci., 14, 189-202.

Barragán, R. and Maurrasse, F.J.-M.R., 2008. Lower Aptian (Lower Cretaceous) ammonites from the basal strata of the La Peña Formation of Nuevo León State, northeast Mexico: biochronostratigraphic implications. Rev. Mex. Cienc. Geol., 25, 145-157.

Barragán-Manzo, R. and Méndez-Franco, A.L., 2005. Towards a standard ammonite zonation for the Aptian (Lower Cretaceous) of northern Mexico. Rev. Mex. Cienc. Geol., 22, 39-47.

Bover-Arnal, T., Salas, R., Moreno-Bedmar, J.A. and Bitzer, K., 2009. Sequence stratigraphy and architecture of a late early-Middle Aptian carbonate platform succession from the western Maestrat Basin (Iberian Chain, Spain). Sed. Geol., 219, 280-301.

Bover-Arnal, T., Moreno-Bedmar, J.A., Salas, R., Skelton, P.W., Bitzer, K. and Gili, E., 2010a. Sedimentary evolution of an Aptian syn-rift carbonate system (Maestrat Basin, E Spain): effects of accommodation and environmental change. Geol. Acta, 8, 249-280.

Bover-Arnal, T., Salas, R., Guimerà, J. and Moreno-Bedmar, J.A., 2010b. Deciphering late Early-Middle Aptian relative sea level fluctuations in the northern Maestrat Basin (Iberian Chain; E Iberia). In: Abstracts Volumen, 18th International Sedimentological Congress (E. Schwarz, S. Georgieff, E. Piovano and D. Ariztegui, eds), pp. 197. International Association of Sedimentologists, Mendoza, Argentina.

Bover-Arnal, T., Salas, R., Martín-Closas, C., Schlagintweit, F. and Moreno-Bedmar, J.A., 2011. Expression of an oceanic anoxic event in a neritic setting: Lower Aptian coral rubble deposits from the western Maestrat Basin (Iberian Chain, Spain). Palaios, 26, 18-32.

Bralower, T.J., CoBabe, E., Clement, B., Sliter, W.V., Osburn, C.L. and Longoria, J., 1999. The record of global change in mid-Cretaceous (Barremian-Albian) sections from the Sierra Madre, northeastern Mexico. J. Foram. Res., 29, 418437.

Burckhardt, C., 1925. Faunas del Aptiano de Nazas (Durango). Mexico. Inst. Geol. Bol., 45, 1-71.

Cantu Chapa, A., 1963. Étude Biostratigraphique des Ammonites du Centre et de l'est du Mexique (Jurassique supérieur et Crétacé). Mém. Soc. Géol France, Nouvelle Série, 42, 102

Cantú Chapa, C.M., 1976. Estratigrafia de la Formación La Peña (Aptiano Sup.) en el área de Monterrey, N. L. Rev. Inst. Mex. Petról., 8, 7-16.

Cecca, F., Vrielynck, B., Lavoyer, T. and Gaget, H., 2005. Changes in the ammonite taxonomical diversity gradient during the late Jurassic-early Cretaceous. J. Biogeogr., 32, 535-547.

Cloetingh, S., 1986. Intraplate stresses: a new tectonic mechanism for fluctuations of relative sea level. Geology, 14, 617620.

Cloetingh, S., 1991. Tectonics and sea-level changes: a controversy? Ice age interludes during the time of Cretaceous greenhouse climate? In: Controversies in Modern Geology: Evolution of Geological Theories in Sedimentology, Earth History and Tectonics (D.W. Müller, J.A. McKenzie and H. Weissert, eds), pp. 249-277. Academic Press, London.

Colombié, C. and Strasser, A., 2005. Facies, cycles, and controls on the evolution of a keep-up carbonate platform (Kimmeridgian, Swiss Jura). Sedimentology, 52, 1207-1227.

Dutour, Y., 2005. Biostratigraphie, évolution et renouvellement des ammonites de l'Aptien supérieur (Gargasien) du bassin vocontien (Sud-Est de la France). Unpubl. doctoral dissertation, Université Claude Bernard Lyon I, 1-302.

Etayo-Serna, F., 1979. Zonation of the Cretaceous of central Colombia by ammonites. Publicaciones Geológicas Especiales del Ingeominas, 2, 1-186.

García-Mondéjar, J., Owen, H.G., Raisossadat, N., Millán, M.I. and FernándezMendiola, P.A., 2009. The Early Aptian of Aralar (northen Spain): stratigraphy, sedimentology, ammonite biozonation, and OAE1. Cretaceous Res., 30, 434 464.

Gradstein, F., Ogg, J. and Smith, A., 2004. A Geologic Time Scale 2004. Cambridge University Press, Cambridge, 589 pp.

Hardenbol, J., Thierry, J., Farley, M.B. Jacquin, T., de Graciansky, P.C. and Vail, P.R., 1998. Mesozoic and Cenozoic sequence chronostratigraphic framework of European basins. In: Mesozoic and Cenozoic Sequence Stratigraphy of European Basins (P.C. De Graciansky, J. Hardenbol, T. Jacquin and P.R. Vail, eds), SEPM Special Publications, 60 , 3-14.

Hill, R.T., 1893. Paleontology of the Cretaceous formations of Texas-The invertebrate paleontology of the Trinity Division. Proc. Biol. Soc. Wash., 8, 9-40. Hillgärtner, H., Van Buchem, F.S.P., Gaumet, F., Razin, P., Pittet, B., Grötsch, J. and Droste, H., 2003. The BarremianAptian evolution of the eastern Arabian carbonate platform margin (northern Oman). J. Sedimentol. Res., 73, 756-773.

Humphrey, W.E., 1949. Geology of Sierra de Los Muertos area, Mexico (with descriptions of Aptian cephalopods from 
the La Peña Formation). Geol. Soc. Am. Bull., 60, 89-176.

Immenhauser, A. and Scott, R.W., 1999. Global correlation of middle Cretaceous sea-level events. Geology, 27, 551-554.

Kennedy, W.J. and Cobban, W.A., 1976. Aspects of ammonite biology, biogeography, and biostratigraphy. Palaeontological Association London, Special Papers in Palaeontology, 17, 94.

Latil, J.L., 2011. Early Albian ammonites from Central Tunisia and adjacent areas of Algeria. Rev. Paléobiol., 30, 321-429.

Millán, M.I., Fernández-Mendiola, P.A. and García-Mondéjar, J., 2007. Pulsos de inundación marina en la terminación de una plataforma carbonatada (Aptiense inferior de Aralar, Cuenca Vasco-Cantábrica). Geogaceta, 41, 127130.

Millán, M.I., Weissert, H.J., FernándezMendiola, P.A. and García-Mondéjar, J., 2009. Impact of Early Aptian carbon cycle perturbations on evolution of a marine shelf system in the Basque-Cantabrian Basin (Aralar, N Spain). Earth Planet. Sci. Lett., 287, 392-401.

Moreno-Bedmar, J.A., 2010. Ammonits de l'Aptià inferior de la península Ibèrica. Biostratigrafia i aportacions a l'estudi del Oceanic Anoxic Event 1a. Unpubl. doctoral dissertation, Universitat de Barcelona, 331 pp. http://www.tdx.cat/ TDX-0316110-140631.

Moreno-Bedmar, J.A., Company, M., Bover-Arnal, T., Salas, R., Delanoy, G. Martínez, R. and Grauges, A., 2009. Biostratigraphic characterization by means of ammonoids of the Lower Aptian Oceanic Anoxic Event (OAE 1a) in the eastern Iberian Chain (Maestrat Basin, eastern Spain). Cretaceous Res., 30, 864-872.

Moreno-Bedmar, J.A., Company, M., Bover-Arnal, T., Salas, R., Delanoy, G., Maurrasse, F.J.-M.R., Grauges, A. and Martínez, R., 2010. Lower Aptian ammonite biostratigraphy in the Maestrat Basin (Eastern Iberian Chain, Eastern Spain). A Tethyan transgressive record enhanced by synrift subsidence. Geol. Acta, 8, 281-299.
Moreno-Bedmar, J.A., Company, M., Sandoval, J., Tavera, J.M., Bover-Arnal, T., Salas, R., Delanoy, G., Maurrasse, F.J.-M.R. and Martínez, R., 2012. Lower Aptian ammonite and carbon isotope stratigraphy in the eastern Prebetic Domain (Betic Cordillera, southeastern Spain). Geol. Acta, 10 , $1-12$.

Najarro, M., Rosales, I., Moreno-Bedmar, J.A., de Gea, G.A., Barrón, E., Company, M. and Delanoy, G., 2011. Highresolution chemo- and biostratigraphic records of the Early Aptian oceanic anoxic event in Cantabria (N Spain): Palaeoceanographic and palaeoclimatic implications. Palaeogeogr. Palaeoclimatol. Palaeoecol., 299, 137-158.

Orbigny, A.d'., 1841. Paléontologie francaise. Description zoologique et géologique de tous les animaux mollusqes et rayonnés fossiles de France. Terrains Crétacés. 1, Céphalopodes. Part II (1841), pp. 121-430. Masson, París.

Pasquier, J.-B. and Strasser, A., 1997. Platform-to-basin correlation by highresolution sequence stratigraphy and cyclostratigraphy (Berriasian, Switzerland and France). Sedimentology, 44, 1071-1092.

Reboulet, S., Rawson, P.F., Moreno-Bedmar, J.A., Aguirre-Urreta, M.B., Barragán, R., Bogomolov, Y., Company, M., González-Arreola, C., Stoyanova, V.I., Lukeneder, A., Matrion, B., Mitta, V., Randrianaly, H. and Vašiček, Z., 2011. Report on the 4 th International Meeting of the IUGS Lower Cretaceous ammonite working group, the "Kilian Group" (Dijon, France, 30th August 2010). Cretaceous Res., 32, 786-793.

Renz, O., 1982. The Cretaceous Ammonites of Venezuela. Birkhaüser Verlag Editions Maraven, Caracas. 132 pp.

Riedel, L., 1938. Amonites del cretácico inferior de la Cordillera Oriental. In: Estudios geológicos y paleontológicos sobre la Cordillera Oriental de Colombia, part 2. Ministerio de Industria y Trabajo (E.A. Scheibe, ed.), pp. 7-80. Departamento de Minas y Petróleos, Bogotá, Colombia.
Röhl, U. and Ogg, J.G., 1998. AptianAlbian eustatic sea-levels. In: Reefs and Carbonate Platforms in the Pacific and Indian Oceans (G.F. Camoin and P.J. Davies, eds), IAS Special Publication, 25, 95-136.

Salas, R., 1987. El Malm i el Cretaci inferior entre el Massís de Garraf i la Serra d'Espadà. Analisi de Conca. Unpubl. doctoral dissertation. Universitat de Barcelona, 345 pp.

Skelton, P.W. and Gili, E., 2012. Rudists and carbonate platforms in the Aptian: a case study on biotic interactions with ocean chemistry and climate. Sedimentology, 59, 81-117.

Sowerby, J.de.C., 1836. Appendix A: Descriptive notes respecting the shells figured in pl. 11 to 23 , (pp. 335-348) In: Observations on some of the Strata Between the Chalk and the Oxford Oolite in the Ssouth-East of England (W.H. Fitton, ed.). Trans. Geol. Soc. London (series 2), 4, 103-390.

Stoyanow, A., 1949. Lower Cretaceous stratigraphy in southeastern Arizona. Geol. Soc. Am. Mem., 38, 1-169.

Vail, P.R., Mitchum. Jr, R.M. and Thompson III, S., 1977. Seismic stratigraphy and global changes of sea level, part 3: relative changes of sea level from coastal onlap. In: Seismic Stratigraphy - Applications to Hydrocarbon Exploration. Memoir ( $A A P G$ ) (C.E. Payton, ed.), 26, pp. 63-81.

Yose, L.A., Ruf, A.S., Strohmenger, C.J., Schuelke, J.S., Gombos, A., Al-Hosani, I., Al-Maskary, S., Bloch, G., Al-Mehairi, Y. and Johnson, I.G., 2006. Threedimensional characterization of a heterogeneous carbonate reservoir, Lower Cretaceous, Abu Dhabi (United Arab Emirates). In: Giant Hydrocarbon Reservoirs of the World: From Rocks to Reservoir Characterization and Modeling (P.M. Harris and L.J. Weber, eds.). AAPG/Society for Sedimentary Geology, 88, 173-212. 